\title{
Deletion of arginine from an abomasal infusion of amino acids does not decrease milk protein yield in Holstein cows
}

\author{
L. Doepel ${ }^{\star 1,2}$ and H. Lapierre† \\ *Department of Agricultural, Food and Nutritional Science, University of Alberta, Edmonton, AB, Canada T6G 2P5 \\ †Dairy and Swine Research and Development Centre, Agriculture and Agri-Food Canada, STN Lennoxville, Sherbrooke, QC, Canada J1M $1 Z 3$
}

\begin{abstract}
This study was undertaken to determine if a limited supply of Arg would alter milk and milk protein yields, as well as mammary uptake of AA and energetic substrates. Six lactating Holstein cows $(199 \pm 5 \mathrm{~d}$ in milk) were used in a replicated $3 \times 3$ Latin square balanced for residual effects with $14-d$ periods. The diet was formulated to supply $100 \%$ of the National Research Council net energy requirement and $72 \%$ of the metabolizable protein requirement. The treatments were randomly distributed as abomasal infusions of (1) water (CTL), (2) a mixture of essential AA (EAA) excluding Arg (ARG-), or (3) a mixture of EAA including Arg $(\mathrm{ARG}+)$. The profile of EAA in the infusates was the same as that found in casein with the exception that methionine was increased to maintain a $3: 1$ ratio of digestible lysine:methionine (total dietary + infusion). Milk protein yield was increased by the ARG+ compared with the CTL treatment and deletion of Arg in the infusate (ARG-) did not impair this response. Deletion of Arg from the EAA mixture decreased the mammary uptake of Arg relative to that of the CTL treatment, and although the uptake:output ratio decreased from $2.52(\mathrm{ARG}+)$ to $2.12(\mathrm{ARG}-)$, it was still largely in excess of Arg secretion in milk protein. Otherwise, Arg deletion did not affect any of the measured parameters (no significant difference between ARG- and ARG+) except Arg and urea arterial concentrations. In support of the increased yields of milk protein and lactose, mammary uptake of the group 2 AA (Ile, Leu, Lys, and Val) increased and the uptake:output ratio tended to increase from 1.04 to 1.23 . The mammary uptake:milk protein output ratio was not different from 1 and not different among treatments for the group 1 AA (His, Met, Phe + Tyr, Trp). Mammary uptake of energetic substrates did not vary across treatments, although
\end{abstract}

\footnotetext{
Received June 2, 2010.

Accepted September 22, 2010.

${ }^{1}$ Corresponding author: ldoepel@ucalgary.ca

${ }^{2}$ Current address: University of Calgary Faculty of Veterinary Medicine, Calgary, AB, Canada T2N 4Z6.
}

milk lactose yield increased with the ARG+ treatment relative to CTL. These results indicate that deletion of Arg has minimal effects on milk and milk component yields when the remaining EAA are supplied in sufficient amounts despite decreased mammary Arg uptake and that group $2 \mathrm{AA}$ seem to be involved in the mammary gland to support the lactose yield response to EAA infusion.

Key words: mammary, milk synthesis, arginine

\section{INTRODUCTION}

Arginine is 1 of the 20 common AA used to synthesize all proteins, including milk protein. Despite the fact that the dairy cow can synthesize Arg, it is normally considered an essential AA (EAA) because de novo synthesis is not sufficient to meet the needs of the high producing cow (NRC, 2001). Although the Arg content of milk protein is relatively low (3.4\% of CP; Swaisgood, 1995), mammary uptake of Arg is relatively high. Indeed, Arg is unique in terms of its mammary gland metabolism in that, in dairy cows, its uptake is 2 to 3 times the amount that appears in milk protein, whereas the mammary uptake:milk output ratio for the other 9 EAA varies between 1 and 1.4 (Bickerstaffe et al., 1974; Clark, 1975; Mepham, 1982).

The Arg taken up in excess by the mammary gland acts as a precursor of Orn (which is subsequently used as a $\mathrm{C}$ precursor for Pro), as a donor of $\mathrm{N}$ in transamination reactions for the synthesis of other nonessential AA (NEAA) such as Glu, Ala, and Ser and for synthesis of the polyamines spermidine and spermine; in addition, Arg also is a precursor of nitric oxide involved in mammary plasma flow regulation (see reviews by Mepham, 1982; Bequette et al., 1998). Proline constitutes approximately $10 \%$ of milk protein (Swaisgood, 1995) and both its net portal appearance (Berthiaume et al., 2006) and its uptake by the mammary gland (Clark, 1975; Doepel and Lapierre, 2010) are far less than the amount secreted in milk protein; thus, it must be synthesized in the gland. Albeit not as severe as for Pro, the uptakes of Ala, Glu, and Ser also are usually smaller than their respective milk protein output (Bick- 
erstaffe et al., 1974; Clark, 1975; Doepel and Lapierre, 2010). In vitro studies (Clark et al., 1975) and studies in perfused mammary glands (Roets et al., 1979) have shown that Pro as well as Ala, Asp, Glu, Gly, and Ser are major end-products of Arg and Orn mammary metabolism.

A few decades ago, Arg supplementation in dairy cows received considerable attention because i.v. injection of Arg increased plasma concentrations of somatotropin, insulin, prolactin, and placental lactogen (Vicini et al., 1988). Supplementation levels were very high and yet i.v. or abomasal administration of Arg was not successful in increasing milk and protein yields in cows (e.g., $178 \mathrm{~g}$ of Arg/d; Vicini et al., 1988). In contrast, duodenal Pro infusions $(80 \mathrm{~g} / \mathrm{d})$ increased milk protein yield in mid lactation dairy cows but not in early lactating cows (Bruckental et al., 1991) or in goats (8 g of Pro/d; Alumot et al., 1983). None of the studies involving Arg supplementation has reported mammary metabolism.

The deficiency created by the deletion of an AA usually yields a greater response than supplementation of the AA (Weekes et al., 2006; Lapierre et al., 2009). It also appears that the response in mammary metabolism in terms of both energy and protein may vary with AA supply (Lemosquet et al., 2010). Our hypothesis was that deletion of Arg from an EAA mixture would affect mammary metabolism of Arg, other AA, and energyyielding nutrients in a coordinated manner so as not to affect yields of milk and protein. Therefore, this study was undertaken to determine how mammary uptake of AA and energy substrates changes when the supply of Arg is altered and to determine if milk protein secretion is limited by Arg supply.

\section{MATERIALS AND METHODS}

\section{Treatments and Feeding}

Four first-lactation and 2 second-lactation Holstein cows averaging $199 \pm 5 \mathrm{DIM}$ and $640 \pm 87 \mathrm{~kg}$ of BW and previously implanted with abomasal catheters (Doepel et al., 2006) were used for this study. Cows had free access to fresh water, were milked twice daily at 0430 and $1530 \mathrm{~h}$, and were cared for according to the Canadian Council on Animal Care (1993). All experimental procedures were approved by the Animal Care and Use Committee of the University of Alberta. The cows were randomly assigned to 1 of 3 treatments in a replicated $3 \times 3$ Latin square design balanced for residual effects with 14-d periods. The treatments were randomly distributed as abomasal infusions of (1) water (control, CTL), (2) a mixture of EAA excluding $\operatorname{Arg}(\mathbf{A R G}-)$, and (3) a mixture of EAA including Arg $(\mathbf{A R G}+)$. The profile of EAA in the infusates (Table
Table 1. Daily amount (g) of AA infused abomasally into the cows

\begin{tabular}{lcc}
\hline & \multicolumn{2}{c}{ Treatment $^{1}$} \\
\cline { 2 - 3 } Amino & ARG - & ARG + \\
\hline Arginine & - & 23.5 \\
Histidine & 18.7 & 18.7 \\
Isoleucine & 40.8 & 40.8 \\
Leucine & 67.8 & 67.8 \\
Lysine & 57.4 & 57.4 \\
Methionine & 22.4 & 22.4 \\
Phenylalanine & 33.9 & 33.9 \\
Threonine & 29.7 & 29.7 \\
Tryptophan & 10.4 & 10.4 \\
Valine & 45.6 & 45.6 \\
Total & 326.7 & 350.2 \\
\hline
\end{tabular}

${ }^{1} \mathrm{ARG}-=$ essential AA infusion excluding Arg; ARG $+=$ essential AA infusion including Arg.

1) was the same as that found in casein with the exception that methionine was increased so that in the total supply of AA (total dietary + infusion), a 3:1 ratio of digestible lysine to methionine was maintained. Arginine was included at $23.5 \mathrm{~g} / \mathrm{d}$ in the ARG+ treatment. Nonessential AA were not included in the infusate as a previous study (Doepel and Lapierre, 2010) found no milk protein yield response to NEAA infusions. The AA were dissolved in hot tap water every 2 or $3 \mathrm{~d}$, and were infused continuously through a peristaltic pump in a daily volume of $8 \mathrm{~L} /$ cow $(333 \mathrm{~mL} / \mathrm{h})$ for the duration of each experimental period.

A TMR was formulated to supply $100 \%$ of the cows' $\mathrm{NE}_{\mathrm{L}}$ requirements but only $72 \%$ of the MP requirements based on a DMI of $20 \mathrm{~kg} / \mathrm{d}$ and a pretrial milk yield of $29.5 \mathrm{~kg} / \mathrm{d}$ (NRC, 2001; Table 2). Cows were fed once daily for the first $10 \mathrm{~d}$ of each period and 6 times daily (every $4 \mathrm{~h}$ ) for the last $4 \mathrm{~d}$ of each period to maintain steady state conditions. Throughout the study, cows were offered the average amount of their ad libitum intake measured the $4 \mathrm{~d}$ before the initiation of the project.

\section{Sampling and Laboratory Analyses}

Feed ingredients were collected weekly, pooled by period, and analyzed for $\mathrm{CP}(\mathrm{N} \times 6.25)$ using a Leco FP-428 Nitrogen Determinator (Leco Corp., St. Joseph, MI), and for ADF and NDF using amylase and sodium sulfite on an Ankom ${ }^{2000}$ fiber analyzer (Ankom Technology, Macedon, NY) according to the procedures described by Van Soest et al. (1991). Milk was sampled at each milking during the last $7 \mathrm{~d}$ of each experimental period. Milk fat, protein, and lactose were measured by infrared spectroscopy (Milk-O-Scan 605; Foss Electric, Hillerød, Denmark) at the Canwest Central Milk Testing Laboratory (Edmonton, AB, Canada). 
On the last day of each period starting at $0500 \mathrm{~h}$, after the morning milking, blood samples were collected by venipuncture into heparinized tubes simultaneously from the coccygeal vessel (considered to be representative of arterial supply; Emery et al., 1965; Cant et al., 1993) and s.c. abdominal vein every $2 \mathrm{~h}$ for $12 \mathrm{~h}$, covering 3 cycles of feeding and 1 milking interval. Immediately after collection, blood was placed on ice and centrifuged $\left(25 \mathrm{~min}, 1,800 \times g\right.$ at $\left.4^{\circ} \mathrm{C}\right)$ within $30 \mathrm{~min}$ of collection. From the resultant plasma, two 1-g aliquots were immediately added to $0.2 \mathrm{~g}$ of 1 of 2 internal AA standards labeled with stable isotopes as described in Doepel and Lapierre (2010), and the processed samples were frozen at $-80^{\circ} \mathrm{C}$ for subsequent $\mathrm{AA}$ analysis. Labeled AA (95-99 atom \%) were supplied by CDN Isotopes (Montreal, QC, Canada) for His, Leu, Lys, Met, and Phe and Cambridge Isotope Lab (Andover, MA) for others. The remainder of the plasma was stored at $-20^{\circ} \mathrm{C}$ for subsequent metabolite analyses.

Plasma AA concentrations were measured by isotope dilution using GC-MS (Calder et al., 1999) with (heptafluorobutyric)AA derivative for Arg, Cit, and Orn, and the $N$-(tert-butyldimethyl)AA derivative for all other AA. Acetate concentrations were determined with a commercial kit modified for a 96-well plate (Enzytec, Scil Diagnostics GmbH, Viernheim, Germany) as outlined in Doepel and Lapierre (2010). $\beta$-Hydroxybutyrate concentrations were determined by the procedure of Williamson and Mellanby (1974) adapted to a 96-well plate format. Glucose concentration was measured with a colorimetric assay (Raabo and Terkildsen, 1960) using a glucose oxidase/peroxidase enzyme (Sigma no. P7119), and dihydrochloride (Sigma no. F5803). LLactate was measured as described by Benson et al. (2002). Plasma urea-N concentrations were measured with an automatic analyzer (Technicon Autoanalyser II, Technicon Instruments Corp., NY) as described previously (Huntington, 1984). Plasma insulin concentrations were determined by RIA using a Coat-A-Count Insulin Kit (Diagnostic Products Corp., Los Angeles, CA). Concentrations of IGF-1 were determined by a double-antibody RIA following acid-ethanol extraction (Novak et al., 2002). Both insulin and IGF-1 were determined in a single assay, with intraassay $\mathrm{CV}$ being $6.8 \%$ and $6.3 \%$ for insulin and IGF-1, respectively.

\section{Calculations}

Mammary plasma flow was estimated according to the Fick principle using Phe and Tyr as internal markers with allowance for a $3.5 \%$ contribution from bloodborne proteins: mammary plasma flow $=[($ milk Phe + Tyr $) \times 0.965] \div($ arterial-venous difference Phe + Tyr $)$ (Cant et al., 1993). Milk AA output was calculated us-
Table 2. Ingredient and nutrient composition of the TMR

\begin{tabular}{lc}
\hline Item & Value \\
\hline Ingredient, \% of diet DM & \\
Alfalfa hay & 10.0 \\
Barley silage & 50.0 \\
Barley grain & 24.5 \\
Beet pulp & 10.0 \\
Canola oil & 2.01 \\
Ca soaps of fatty acids ${ }^{1}$ & 0.97 \\
Vitamin/mineral premix ${ }^{2}$ & 0.97 \\
Dicalcium phosphate & 0.87 \\
Vitamin E, 5,000 IU/kg & 0.36 \\
Salt & 0.19 \\
Magnesium oxide & 0.08 \\
Nutrients & \\
NE ${ }^{3}$ Mcal/kg & 1.63 \\
CP, \% & 11.7 \\
ADF, \% & 18.2 \\
NDF, \% & 31.0 \\
Ca, \% & 0.80 \\
P, \% & 0.40 \\
Mg, \% & 0.24 \\
K, \% ${ }^{3}$ g/d & 1.30 \\
MP, & 1,508 \\
\hline
\end{tabular}

${ }^{1}$ Megalac, Church \& Dwight Co. Inc., Princeton, NJ.

${ }^{2}$ Contained $0.1 \% \mathrm{Ca}, 0.6 \% \mathrm{P}, 0.3 \% \mathrm{Mg}, 11.5 \% \mathrm{Na}, 0.23 \% \mathrm{~S}, 6.2 \mathrm{mg}$ of $\mathrm{Co} / \mathrm{kg}, 1,170 \mathrm{mg}$ of $\mathrm{Cu} / \mathrm{kg}, 80 \mathrm{mg}$ of I/kg, $100 \mathrm{mg}$ of Mn/kg, $40 \mathrm{mg}$ of $\mathrm{Se} / \mathrm{kg}, 5,000 \mathrm{mg}$ of $\mathrm{Zn} / \mathrm{kg}, 1,265,000 \mathrm{IU}$ of vitamin A/kg, 142,000 IU of vitamin $\mathrm{D} / \mathrm{kg}$, and $3,800 \mathrm{IU}$ of vitamin $\mathrm{E} / \mathrm{kg}$.

${ }^{3}$ Calculated based on DMI of $20 \mathrm{~kg} / \mathrm{d}$ (NRC, 2001).

ing milk protein yield measured on the last day of each period, with a $3.5 \%$ correction for bloodborne proteins, and AA composition analyzed for this study (mg of AA/g of true protein: Ala, 36.2; Gly, 20.6; His, 30.2; Leu, 110.0; Lys, 92.8; Phe, 53.8; Pro, 106.8; Thr, 49.0; Tyr, 56.2) or calculated from an average composition of milk protein fractions and AA composition when not available from our analysis (Asn, 42.4; Asp, 35.4; Arg, 36.2; Cys, 7.1; Gln, 98.9; Glu, 126.3; Ile, 61.4; Met, 30.7; Ser, 62.9; Trp, 14.9; Val, 69.2; adapted from Swaisgood, 1995). Nutrient uptakes across the mammary gland were calculated for each cow in each period as the product of the average plasma arterio-venous concentration difference and the average plasma flow.

\section{Statistical Analysis}

Before statistical analysis, metabolite concentrations and net flux data were averaged over the 6 sampling times for each cow on d 14 of each period, and DMI, milk yield, and milk composition were averaged over the last $7 \mathrm{~d}$ of each period. All data were statistically analyzed using the MIXED procedure of SAS (SAS Institute, 1999), with treatment, period, and cow as fixed effects. Treatment differences were determined with PDIFF using the Tukey-Kramer adjustment, and were considered significant if $P \leq 0.05$ and as a trend for 
Table 3. Effect of AA infusions on DMI and milk production and composition

\begin{tabular}{lccccc}
\hline & \multicolumn{3}{c}{ Treatment $^{1}$} & & \\
\cline { 2 - 4 } Item & CTL & ARG- & ARG + & SEM & $P$-value \\
\hline DMI, kg/d & 19.9 & 19.7 & 20.0 & 0.10 & 0.31 \\
Milk yield, kg/d & $24.8 \dagger$ & 26.2 & 26.3 & 0.49 & 0.10 \\
Protein yield, g/d & $769^{\mathrm{a}}$ & $845^{\mathrm{b}}$ & $843^{\mathrm{b}}$ & 15.5 & 0.01 \\
Lactose yield, g/d & $1,101^{\mathrm{a}}$ & $1,164^{\mathrm{ab}}$ & $1,179^{\mathrm{b}}$ & 19.5 & 0.05 \\
Fat yield, g/d & 643 & 622 & 618 & 15.8 & 0.51 \\
Milk composition & & & & & \\
Protein, \% & $3.12 \dagger$ & $3.24 \dagger$ & 3.21 & 0.03 & 0.07 \\
NPN, \% of CP & $6.07^{\mathrm{a}}$ & $5.75^{\mathrm{b}}$ & $6.01^{\mathrm{a}}$ & 0.06 & 0.02 \\
Lactose, \% & 4.43 & 4.43 & 4.45 & 0.02 & 0.54 \\
Fat, \% & 2.62 & 2.40 & 2.37 & 0.09 & 0.14 \\
\hline
\end{tabular}

${ }^{\mathrm{a}, \mathrm{b}}$ Treatments within the same row with a different superscript differ $(P \leq 0.05)$.

${ }^{1} \mathrm{CTL}=$ water; ARG $-=$ essential AA infusion excluding Arg; ARG $+=$ essential AA infusion including Arg. $\dagger$ Indicates that the values tended to be different with $0.05<P \leq 0.10$; milk yield of CTL tended to be lower than for ARG- and ARG+.

$0.05<P \leq 0.10$. All data are reported as least squares means with pooled standard errors (SEM).

\section{RESULTS}

\section{DMI and Milk Yield}

Dry matter intake, milk yield, and milk composition are shown in Table 3. Because of the restrictions imposed on intake during the course of the experiment, treatment did not affect DMI $(P=0.31)$. Milk yield tended to be affected by treatments $(P=0.10)$; yields were higher for cows receiving ARG - and ARG+ than for those receiving CTL. Milk protein yield $(P=0.01)$ and percent $(P=0.07)$ were higher for the cows receiving $\mathrm{ARG}-$ and $\mathrm{ARG}+$ than for those receiving CTL, but no differences were found between ARG- and ARG+. Milk lactose yield also was increased by AA infusion $(P=0.05)$, although the difference was significant only between ARG+ and CTL, whereas milk lactose percentage was not different among treatments
$(P=0.54)$. Milk fat yield (average of $628 \mathrm{~g} / \mathrm{d})$ and milk fat content $(2.46 \%)$ were not different among the treatments.

\section{Metabolite Arterial Concentrations}

Acetate, BHBA, glucose, and lactate arterial concentrations were not affected by treatment $(P>0.40$, Table 4), and averaged 1.08, 0.91, 4.11, and $0.74 \mathrm{mM}$, respectively. Urea concentrations were increased $(P<$ 0.01, Table 4) with ARG + and ARG - compared with CTL. Insulin and IGF-1 concentrations were not different among treatments $(P>0.50$, Table 4$)$.

Amino acid arterial concentrations are shown in Table 5. As expected, arterial concentrations of the EAA (His, Ile, Leu, Lys, Met, Phe, Thr, Trp, Val) were higher ( $P$ $<0.05)$ when ARG- and ARG+ were infused compared with CTL. Arginine concentration was increased with the ARG + treatment only $(P=0.001)$. Citrulline, Cys, and Orn concentrations increased with infusions of AA; the concentrations were higher $(P<0.05)$ with the

Table 4. Effect of AA infusions on arterial metabolite, insulin, and IGF-1 concentrations

\begin{tabular}{lccccc}
\hline & \multicolumn{3}{c}{ Treatment $^{1}$} \\
\cline { 2 - 3 } Parameter $^{2}$ & CTL & ARG- & ARG + & SEM & P-value \\
\hline Acetate, $\mathrm{m} M$ & 1.05 & 1.12 & 1.07 & 0.04 & 0.54 \\
BHBA, $\mathrm{m} M$ & 0.87 & 0.96 & 0.90 & 0.09 & 0.76 \\
Glucose, $\mathrm{m} M$ & 4.10 & 4.15 & 4.08 & 0.05 & 0.56 \\
Lactate, $\mathrm{m} M$ & 0.71 & 0.65 & 0.85 & 0.10 & 0.41 \\
Urea-N, $\mathrm{m} M$ & $7.19^{\mathrm{a}}$ & $7.89^{\mathrm{b}}$ & $8.29^{\mathrm{b}}$ & 0.17 & 0.005 \\
Insulin, $\mu \mathrm{IU} / \mathrm{mL}$ & 12.2 & 13.5 & 12.9 & 1.19 & 0.76 \\
IGF-1, $\mathrm{ng} / \mathrm{mL}$ & 160 & 165 & 174 & 8.0 & 0.51 \\
\hline
\end{tabular}

${ }^{\mathrm{a}, \mathrm{b}}$ Treatments within the same row with a different superscript differ $(P \leq 0.05)$.

${ }^{1} \mathrm{CTL}=$ water; $\mathrm{ARG}-=$ essential AA infusion excluding Arg; ARG $+=$ essential AA infusion including Arg. ${ }^{2}$ Blood was obtained 6 times (every $2 \mathrm{~h}$ ) on the last day of each period, except for insulin and IGF-1, which was collected 3 times (every $4 \mathrm{~h}$ ) 
Table 5. Effect of AA infusions on arterial AA concentrations $(\mu M)$

\begin{tabular}{|c|c|c|c|c|c|}
\hline \multirow{2}{*}{$\begin{array}{l}\text { Amino } \\
\operatorname{acid}^{2}\end{array}$} & \multicolumn{3}{|c|}{ Treatment $^{1}$} & \multirow[b]{2}{*}{ SEM } & \multirow[b]{2}{*}{$P$-value } \\
\hline & CTL & ARG- & $\mathrm{ARG}+$ & & \\
\hline Alanine & 234.0 & 215.3 & 223.4 & 9.32 & 0.41 \\
\hline Arginine & $83.8^{\mathrm{a}}$ & $82.3^{\mathrm{a}}$ & $108.2^{\mathrm{b}}$ & 3.44 & 0.001 \\
\hline Aspartate & 38.0 & 34.9 & 33.1 & 4.32 & 0.73 \\
\hline Citrulline & $84.2^{\mathrm{a}} \dagger$ & $111.3^{\mathrm{ab}_{\dagger}}$ & $117.7^{\mathrm{b}}$ & 7.65 & 0.02 \\
\hline Cysteine & $78.6^{\mathrm{a}}$ & $93.9^{\mathrm{b}}$ & $93.6^{\mathrm{b}}$ & 2.68 & 0.006 \\
\hline Glutamate & $54.8^{\mathrm{a}}$ & $53.6^{\mathrm{ab}}$ & $51.4^{\mathrm{b}}$ & 0.75 & 0.03 \\
\hline Glutamine & $251.4 \dagger$ & 237.0 & $232.8 \dagger$ & 5.20 & 0.08 \\
\hline Glycine & $401.8^{\mathrm{a}}+$ & $346.2^{\mathrm{ab} \dagger}$ & $337.0^{\mathrm{b}}$ & 13.03 & 0.03 \\
\hline Histidine & $25.4^{\mathrm{a}}$ & $56.3^{\mathrm{b}}$ & $60.7^{\mathrm{b}}$ & 3.22 & $<0.001$ \\
\hline Isoleucine & $106.0^{\mathrm{a}}$ & $161.6^{\mathrm{b}}$ & $147.4^{\mathrm{b}}$ & 9.20 & 0.007 \\
\hline Leucine & $96.3^{\mathrm{a}}$ & $197.0^{\mathrm{b}}$ & $187.8^{\mathrm{b}}$ & 10.61 & $<0.001$ \\
\hline Lysine & $60.6^{\mathrm{a}}$ & $105.0^{\mathrm{b}}$ & $116.7^{\mathrm{c}}$ & 3.43 & $<0.001$ \\
\hline Methionine & $22.6^{\mathrm{a}}$ & $37.5^{\mathrm{b}}$ & $37.9^{\mathrm{b}}$ & 1.50 & $<0.001$ \\
\hline Ornithine & $41.0^{\mathrm{a}}$ & $52.9^{\mathrm{ab}}$ & $62.1^{\mathrm{b}}$ & 4.79 & 0.04 \\
\hline Phenylalanine & $35.7^{\mathrm{a}}$ & $48.1^{\mathrm{b}}$ & $47.8^{\mathrm{b}}$ & 1.26 & $<0.001$ \\
\hline Proline & $74.2^{\mathrm{a}}$ & $66.6^{\mathrm{b}}$ & $68.5^{\mathrm{ab}}$ & 1.92 & 0.05 \\
\hline Serine & $101.1^{\mathrm{a}}$ & $79.9^{\mathrm{b}}$ & $83.7^{\mathrm{ab}}$ & 5.35 & 0.05 \\
\hline Threonine & $72.4^{\mathrm{a}}$ & $117.8^{\mathrm{b}}$ & $121.7^{\mathrm{b}}$ & 3.78 & $<0.001$ \\
\hline Tryptophan & $41.4^{\mathrm{a}}$ & $50.8^{\mathrm{b}}$ & $52.6^{\mathrm{b}}$ & 1.04 & $<0.001$ \\
\hline Tyrosine & 36.9 & 34.1 & 32.4 & 1.43 & 0.14 \\
\hline Valine & $197.6^{\mathrm{a}}$ & $339.3^{\mathrm{b}}$ & $323.5^{\mathrm{b}}$ & 15.88 & $<0.001$ \\
\hline EAA-N ${ }^{3}$ & $811^{\mathrm{a}}$ & $1,382^{\mathrm{b}}$ & $1,387^{\mathrm{b}}$ & 50.7 & $<0.001$ \\
\hline NEAA-N ${ }^{3}$ & $1,604 \dagger$ & $1,471 \dagger$ & 1,461 & 41.5 & 0.05 \\
\hline
\end{tabular}

${ }^{\mathrm{a}-\mathrm{c}}$ Treatments within the same row with a different superscript differ $(P \leq 0.05)$.

${ }^{1} \mathrm{CTL}=$ water; $\mathrm{ARG}-=$ essential AA infusion excluding Arg; ARG+ = essential AA infusion including Arg. ${ }^{2}$ Blood was obtained 6 times (every $2 \mathrm{~h}$ ) on the last day of each period.

${ }^{3} \mathrm{EAA}-\mathrm{N}=$ essential AA-N; NEAA-N = nonessential AA-N.

$\dagger$ Indicates that the values tended to be different with $0.05<P \leq 0.10$.

ARG + treatment than with CTL, whereas the difference reached significance only for Cys $(P<0.05)$ and Cit $(P=0.07)$ when comparing ARG- and CTL. Concentrations of Glu and Gly were lower $(P \leq 0.05)$ with $\mathrm{ARG}+$ than with CTL; concentrations of Pro and Ser were lower with ARG - than with CTL. Concentrations of Gln tended to be lower $(P=0.08)$ with ARG+ than with CTL. Globally, concentrations of EAA increased with infusions of EAA, with or without Arg, whereas concentrations of NEAA decreased $(P<0.05)$.

\section{Mammary Plasma Flow and Nutrient Uptake}

Mammary plasma flow was lower $(P=0.01)$ with the ARG - treatment than with the CTL treatment, but was not different between ARG- and ARG+ (Table 6). Mammary uptake of individual energetic precursors did not differ among the treatments (Table 6) with uptake of acetate, BHBA, glucose, and lactate averaging 358, 127,389 , and $147 \mathrm{mmol} / \mathrm{h}$, respectively.

Table 7 shows mammary uptake of the AA. Arginine uptake was higher $(P=0.005)$ with $\mathrm{ARG}+$ compared

Table 6. Mammary plasma flow and uptake of plasma metabolites

\begin{tabular}{lccccc}
\hline & \multicolumn{3}{c}{ Treatment $^{1}$} & & \\
\cline { 2 - 3 } Item & CTL & ARG- & ARG + & SEM & $P$-value \\
\hline Plasma flow, L/h & $591^{\mathrm{b}_{\dagger}}$ & $490^{\mathrm{a}}$ & $524^{\mathrm{ab}} \dagger$ & 18.3 & 0.01 \\
Uptake, $^{2} \mathrm{mmol} / \mathrm{h}$ & & & & & \\
Acetate & 386 & 335 & 354 & 25.2 & 0.39 \\
BHBA & 130 & 113 & 138 & 20.2 & 0.68 \\
Glucose & 417 & 387 & 363 & 30.9 & 0.50 \\
Lactate & 104 & 127 & 210 & 56.0 & 0.41 \\
\hline
\end{tabular}

${ }^{\mathrm{a}, \mathrm{b}}$ Treatments within the same row with a different superscript differ $(P \leq 0.05)$.

${ }^{1} \mathrm{CTL}=$ water; $\mathrm{ARG}-=$ essential AA infusion excluding Arg; ARG $+=$ essential AA infusion including Arg.

${ }^{2}$ Blood was obtained 6 times (every $2 \mathrm{~h}$ ) on the last day of each period.

$\dagger$ Indicates that the values tended to be different with $0.05<P \leq 0.10$. 
Table 7. Effect of AA infusions on mammary gland AA uptake (mmol/h)

\begin{tabular}{|c|c|c|c|c|c|}
\hline \multirow{2}{*}{$\begin{array}{l}\text { Amino } \\
\operatorname{acid}^{2}\end{array}$} & \multicolumn{3}{|c|}{ Treatment $^{1}$} & \multirow[b]{2}{*}{ SEM } & \multirow[b]{2}{*}{$P$-value } \\
\hline & CTL & ARG- & $\mathrm{ARG}+$ & & \\
\hline Alanine & 4.0 & 6.5 & 4.6 & 4.70 & 0.92 \\
\hline Arginine & $14.8^{\mathrm{a}}$ & $15.0^{\mathrm{a}}$ & $18.2^{\mathrm{b}}$ & 0.57 & 0.005 \\
\hline Aspartate & 4.8 & 4.6 & 5.6 & 1.20 & 0.82 \\
\hline Citrulline & 0.8 & 2.2 & 10.1 & 5.66 & 0.40 \\
\hline Cysteine & 1.9 & 2.2 & 2.4 & 0.28 & 0.37 \\
\hline Glutamate & $17.5^{\mathrm{b}}$ & $14.2^{\mathrm{a}}$ & $14.8^{\mathrm{a}}$ & 0.60 & 0.01 \\
\hline Glutamine & 38.8 & 34.5 & 38.0 & 2.03 & 0.34 \\
\hline Glycine & 3.2 & 3.1 & 4.1 & 0.83 & 0.69 \\
\hline Histidine & $6.0^{\mathrm{a}}$ & $6.3^{\mathrm{ab}}$ & $6.8^{b}$ & 0.19 & 0.05 \\
\hline Isoleucine & $15.4^{\mathrm{a}}$ & $18.8^{\mathrm{ab}}$ & $20.7^{\mathrm{b}}$ & 1.24 & 0.04 \\
\hline Leucine & $25.3^{\mathrm{a}}$ & $29.6^{\mathrm{ab}}$ & $32.2^{\mathrm{b}}$ & 1.50 & 0.03 \\
\hline Lysine & $20.3^{\mathrm{a}}$ & $26.0^{\mathrm{b}}$ & $28.2^{\mathrm{b}}$ & 0.97 & 0.001 \\
\hline Methionine & $6.3 \dagger$ & 6.8 & $7.3 \dagger$ & 0.28 & 0.10 \\
\hline Ornithine & 11.6 & 9.4 & 14.8 & 2.51 & 0.35 \\
\hline Phenylalanine & $10.6 \dagger$ & 11.2 & $12.2 \dagger$ & 0.43 & 0.07 \\
\hline Proline & 4.5 & 4.9 & 4.7 & 0.52 & 0.87 \\
\hline Serine & 8.8 & 11.2 & 10.8 & 1.80 & 0.62 \\
\hline Threonine & $13.0 \dagger$ & 13.7 & $15.0 \dagger$ & 0.48 & 0.06 \\
\hline Tryptophan & $2.7^{\mathrm{a}}$ & $3.0^{\mathrm{ab}}$ & $3.3^{\mathrm{b}}$ & 0.11 & 0.02 \\
\hline Tyrosine & 9.6 & 9.8 & 10.3 & 0.40 & 0.49 \\
\hline Valine & $21.1^{\mathrm{a}}$ & $23.6^{\mathrm{ab}}$ & $26.4^{\mathrm{b}}$ & 1.26 & 0.05 \\
\hline Group 1 AA-N ${ }^{3}$ & $47^{\mathrm{a}}$ & $50^{\mathrm{ab}}$ & $53^{\mathrm{b}}$ & 1.4 & 0.04 \\
\hline Group 2 AA-N ${ }^{4}$ & $102^{\mathrm{a}} \dagger$ & $124^{\mathrm{ab}} \dagger$ & $136^{\mathrm{b}}$ & 5.8 & 0.01 \\
\hline EAA-N ${ }^{5}$ & $156^{\mathrm{a}} \dagger$ & $181^{\mathrm{ab}}$ & $197^{\mathrm{b}}$ & 7.1 & 0.01 \\
\hline NEAA-N ${ }^{5}$ & 140 & 126 & 150 & 8.7 & 0.19 \\
\hline
\end{tabular}

${ }^{\mathrm{a}, \mathrm{b}}$ Treatments within the same row with a different superscript differ $(P \leq 0.05)$.

${ }^{1} \mathrm{CTL}=$ water; $\mathrm{ARG}-=$ essential AA infusion excluding Arg; ARG $+=$ essential AA infusion including Arg.

${ }^{2}$ Blood was obtained 6 times (every $2 \mathrm{~h}$ ) on the last day of each period.

${ }^{3}$ Group 1 AA-N $=$ His, Met, Phe, Trp, and Tyr.

${ }^{4}$ Group 2 AA-N = Ile, Leu, Lys, and Val.

${ }^{5} \mathrm{EAA}-\mathrm{N}=$ essential AA-N; NEAA-N $=$ nonessential AA-N, excluding Orn and Cit.

$\dagger$ Indicates that the values tended to be different with $0.05<P \leq 0.10$; uptake of EAAN-N tended to be lower for CTL than for ARG- and ARG+.

with ARG- and CTL, whereas uptake of Lys was higher $(P<0.01)$ with the ARG+ and ARG - treatments relative to CTL, and uptakes of His, Ile, Leu, Trp, and Val were higher $(P<0.05)$ with ARG+ compared with CTL and were numerically higher for ARG - than CTL. Uptake of Met and Phe tended to be higher with ARG+ compared with CTL. Uptake of the group 1 AA (His, Met, Phe + Tyr, and Trp) was influenced by treatment $(P=0.04)$; uptake was higher with $\mathrm{ARG}+$ compared with CTL, but was not different between ARG+ and ARG - $(P>0.10)$. Uptake of group 2 AA-N (Ile, Leu, Lys, and Val) was lower for CTL compared with ARG+ $(P=0.01)$ and ARG $-(P=0.07)$. With the exception of Glu, whose uptake was lower with both AA treatments compared with CTL, uptake of the NEAA was not different among the treatments.

Mammary uptake:milk protein output ratios are shown in Table 8. Of the EAA, only the uptake:output ratios of Arg and Lys were affected by treatment. The ratio for Arg was higher with ARG+ compared with $\mathrm{ARG}$ - but was not different between ARG- and CTL, whereas the ratio for Lys was higher with $\mathrm{ARG}+$ and ARG - compared with CTL. The uptake:output ratio of group 2 AA-N tended to be higher $(P=0.07)$ for ARG+ relative to CTL. The uptake:output ratios of the NEAA were not affected by treatment, with the exception of Gln and Glu. For Gln, the ratio was higher with the CTL treatment relative to the ARG- treatment but was not different between CTL and ARG+, whereas for Glu, the ratio was higher with CTL compared with both ARG - and ARG + and was not different between ARG- and ARG+.

\section{DISCUSSION}

\section{Milk Yield and Composition}

The increment in milk protein yield with EAA, with or without Arg, was obtained through a tendency for an increment in both milk yield and milk protein concentration. A milk protein response to infusions of EAA (Metcalf et al., 1996; Doepel and Lapierre, 2010) 
Table 8. Effect of AA infusions on mammary AA uptake:milk protein output ratio

\begin{tabular}{|c|c|c|c|c|c|}
\hline \multirow{2}{*}{$\begin{array}{l}\text { Amino } \\
\operatorname{acid}^{2}\end{array}$} & \multicolumn{3}{|c|}{ Treatment $^{1}$} & \multirow[b]{2}{*}{ SEM } & \multirow[b]{2}{*}{$P$-value } \\
\hline & CTL & ARG- & $\mathrm{ARG}+$ & & \\
\hline Alanine & 0.28 & 0.43 & 0.25 & 0.32 & 0.91 \\
\hline Arginine & $2.27^{\mathrm{ab}}$ & $2.12^{\mathrm{a}}$ & $2.52^{\mathrm{b}}$ & 0.08 & 0.02 \\
\hline Aspartate & 0.63 & 0.50 & 0.56 & 0.16 & 0.85 \\
\hline Cysteine & 1.04 & 1.15 & 1.09 & 0.15 & 0.88 \\
\hline Glutamate & $0.67^{\mathrm{b}}$ & $0.48^{\mathrm{a}}$ & $0.49^{\mathrm{a}}$ & 0.02 & 0.001 \\
\hline Glutamine & $1.82^{\mathrm{b}} \dagger$ & $1.47^{\mathrm{a}}$ & $1.60^{\mathrm{ab}_{\dagger}}$ & 0.06 & 0.001 \\
\hline Glycine & 0.37 & 0.34 & 0.40 & 0.09 & 0.88 \\
\hline Histidine & 0.99 & 0.96 & 0.99 & 0.04 & 0.77 \\
\hline Isoleucine & 1.05 & 1.17 & 1.27 & 0.07 & 0.15 \\
\hline Leucine & 0.97 & 1.03 & 1.10 & 0.05 & 0.17 \\
\hline Lysine & $1.04^{\mathrm{a}} \dagger$ & $1.20^{\mathrm{ab}} \dagger$ & $1.27^{\mathrm{b}}$ & 0.04 & 0.01 \\
\hline Methionine & 0.99 & 0.96 & 1.01 & 0.02 & 0.25 \\
\hline Proline & 0.15 & 0.15 & 0.13 & 0.01 & 0.70 \\
\hline Serine & 0.46 & 0.55 & 0.52 & 0.09 & 0.79 \\
\hline Threonine & 1.01 & 0.97 & 1.04 & 0.03 & 0.27 \\
\hline Tryptophan & 1.19 & 1.25 & 1.30 & 0.06 & 0.41 \\
\hline Valine & 1.14 & 1.16 & 1.28 & 0.06 & 0.21 \\
\hline Group 1 AA-N ${ }^{3}$ & 1.01 & 0.98 & 1.02 & 0.02 & 0.42 \\
\hline Group $2 \mathrm{AA}-\mathrm{N}^{4}$ & $1.04 \dagger$ & 1.14 & $1.23 \dagger$ & 0.05 & 0.07 \\
\hline EAA-N ${ }^{5}$ & 0.98 & 1.04 & 1.11 & 0.04 & 0.11 \\
\hline NEAA-N ${ }^{5}$ & $0.29 \dagger$ & $0.24 \dagger$ & 0.27 & 0.01 & 0.10 \\
\hline
\end{tabular}

has already been observed thus the EAA infusion was chosen to demonstrate that the cows were in responsive condition to AA supply. The recovery of the infused AA into milk protein was $25 \%$ for the ARG - treatment and $21 \%$ for the ARG+ treatment, values in a range similar to that previously reported with infusions of casein or EAA (Hanigan et al., 1998; Raggio et al., 2006; Doepel and Lapierre, 2010).

The lack of a milk yield and milk protein yield response to Arg supplementation is similar to that reported by Vicini et al. (1988). In that study, Arg was infused, abomasally or i.v., at a very high rate (178 $\mathrm{g} / \mathrm{d}$ for $6 \mathrm{~d}$ ), more to stimulate secretion of hormones than for AA supply per se, and yet no differences in milk yield were observed between those cows and cows receiving saline. Direct provision of Pro, one of the endproducts of Arg taken up in excess by the mammary gland, yielded equivocal results as duodenal infusion of Pro in early lactation dairy cows had no effect on milk protein yield whereas it increased milk protein yield in mid lactation cows by 14\% (Bruckental et al., 1991). In goats, duodenal infusion of Pro was ineffective in increasing yields of milk and milk protein (Alumot et al., 1983).
Lactose concentration in milk did not decrease with AA infusions, in contrast with the decrease previously reported for EAA and total AA infusions (Metcalf et al. 1996; Doepel and Lapierre, 2010). With the tendency for the increased milk yield, this resulted in increased lactose yield when EAA were infused, as reported by Doepel and Lapierre (2010). The exact role of EAA in stimulating lactose secretion is not elucidated at the current time. Fat yield did not increase with the ARGand ARG+ treatments, although milk yield tended be higher with these treatments; this was related to the numerically lower milk fat percentage with these treatments. Contrary to our results, Pro supplementation has been shown to increase fat concentration, both in cows (Bruckental et al., 1991) and goats (Alumot et al., 1983). No explanation can be offered for these discrepancies. In the current study, milk fat content was unusually low (resulting in a fat:protein reversal) with all treatments, which is difficult to explain considering dietary NDF and physically effective fiber should have been sufficient to maintain normal $(\geq 3.5 \%)$ milk fat.

Overall, in the current study, it appears that Arg supply (dietary and de novo synthesis) in the ARG- cows was not limiting for milk and milk protein synthesis, as 
deletion of Arg from the EAA infusate did not impair the milk response to EAA supply. Examination of net balance of nutrients across the mammary gland may help to explain how the cows coped with this deletion to maintain their milk and milk protein response.

\section{Amino Acids}

As expected, EAA arterial concentrations increased with the ARG - and ARG + treatments relative to CTL. With the exception of Arg, which was only elevated with the ARG+ treatment, EAA concentrations did not differ between ARG- and ARG+. This last observation is consistent with observations from Vicini et al. (1988) who noted no changes in EAA concentrations with an Arg infusion. Changes in NEAA concentrations in response to treatment were not as consistent. The higher concentrations of $\mathrm{Cit}$ and Orn observed with ARG+ compared with CTL were probably due to conversion from the infused Arg, stimulation of the urea cycle, or both. With ARG- compared with CTL, only Cit tended to increase, probably in relation with the latter explanation. Increased conversion of Arg into Orn must have occurred mainly within the liver as the mammary net uptake of Orn was not altered by EAA infusion. Vicini et al. (1988) also reported an increase in the arterial concentration of Orn in response to an abomasal Arg infusion. The concentration of Cys also increased because of the Met that was infused. Lower Pro concentrations observed with the ARG - treatment relative to CTL is probably due to the increased demand for Pro secreted in milk protein without a concomitant supply of Pro or Arg, considering that Arg is partially converted to Pro in the small intestine (Bertolo et al., 2003) and mammary gland (Clark et al., 1975). The decrease in concentration of Gln, Glu, Gly, and Ser with ARG-, ARG+, or both could be related to the hypothesis that the increase in concentration of NEAA with low protein intake (CTL) allows the animal to conserve the $\alpha$-amino $\mathrm{N}$ group within the body (Grimble and Whitehead, 1970).

Mammary uptake of Arg decreased (by $3.2 \mathrm{mmol} / \mathrm{h}$ ) with Arg deletion from the AA infusate and was approximately equal to CTL despite a higher milk protein yield. As a result, the uptake:output ratio of Arg decreased with Arg deletion, but was still greater than 2 . These observations agree with a meta-analysis that indicated that Arg uptake is related to supply and always in excess of milk protein secretion but its uptake:output ratio is not related to supply (Raggio, 2006). Of all the AA measured in the current study (Asn could not be measured due to technical problems), none exhibited a higher uptake when Arg was deleted from the infusate to compensate for the decreased Arg uptake and to sustain the increased milk protein yield. However, there was probably no need to compensate for this loss: cows with the ARG + treatment had a positive $\mathrm{N}$ balance across the mammary gland $(81 \mathrm{mmol}$ of $\mathrm{N} / \mathrm{h})$, which decreased but still remained positive, averaging 24 and $11 \mathrm{mmol}$ of $\mathrm{N} / \mathrm{h}$ for the CTL and ARG-treatments, respectively (when uptake of Cit and Orn was included in the calculations). Part of the excess $\mathrm{N}$ taken up with the ARG+ treatment was probably released as urea and not used for the synthesis of NEAA: synthesis of Pro from Arg results in the formation of urea under the action of arginase present in the bovine mammary gland (Basch et al., 1997). Also, increased uptake of Arg within the ARG + cows did not result in changes in uptake of Pro or other AA for which Arg had been shown to contribute to mammary synthesis, such as Asp, Ala, Gly, Glu, and Ser.

Mammary uptake of the individual EAA increased with ARG+ compared with CTL, whereas the increment was only numerical for ARG-. Similarly, taken together, mammary uptake of the group $1 \mathrm{AA}$ increased with the ARG- (numerical increase) and ARG+ (significant increase) treatments in line with the increased milk protein output associated with these 2 treatments. Overall, this translated in a consistent mammary uptake:milk protein output ratio of unity across treatments of the group $1 \mathrm{AA}$. This indicates that these AA were used almost exclusively for milk protein synthesis, on a net basis, regardless of level of AA supply. Such results have commonly been reported in the literature (see review from Rulquin et al., 2007). The mammary uptake of group 2 AA increased with EAA infusion, as was also described in the meta-analysis of Rulquin et al. (2007). Taken together, net mammary uptake of group $2 \mathrm{AA}$ increased with EAA infusions at a higher rate than milk protein secretion for both $A R G-$ and $\mathrm{ARG}+$. This resulted in an increased uptake:output ratio for ARG + treatment relative to CTL. It has been reported that in response to an increase in Lys supply, part of the increased uptake is used for the synthesis of NEAA (Lapierre et al., 2009). This suggests that with EAA infusion, in addition to being used for secretion as milk protein, group $2 \mathrm{AA}$ contributed to a greater extent to the synthesis of the NEAA. Indeed the uptakes of the latter were less than their output in milk protein, as previously reported (Clark, 1975; Mepham, 1982; Doepel et al., 2007), and the uptake:output ratio of NEAA decreased with ARG-treatment.

\section{Energy-Yielding Nutrients}

Arterial plasma concentrations of energy-yielding metabolites (acetate, BHBA, glucose, and lactate) did not decrease with the ARG- and ARG + treatments 
and their respective mammary uptake did not differ among treatments although milk yield was $1.5 \mathrm{~kg} / \mathrm{d}$ higher than with CTL and energy intake by the cows was held constant throughout the study. This indicates that the mammary gland had to obtain its energy from other nutrients. The extra ATP required to support the increased protein synthesis may have been provided by the increased group 2 AA (Lemosquet et al., 2010). In this study, acetate and BHBA did not appear to be used to supply additional energy or for milk synthesis as their uptake did not increase with AA infusion and milk fat yield was equal across the 3 treatments.

\section{Urea, Insulin, and IGF-1}

Clark (1975) proposed that an increased supply of AA elicits a milk yield response via an effect on galactopoietic hormones; however, in the current study, neither insulin nor IGF-1 increased in response to ARG- or $\mathrm{ARG}+$. This is in contrast to Chew et al. (1984), who infused Arg i.v. over a 5-min period in nonlactating Holstein cows and reported a significant increase in insulin concentration. This increase, however, was transient, lasting only $1.5 \mathrm{~h}$. It appears that the insulin response to Arg only occurs when a rapid injection of Arg is given because an i.v. injection evoked a 30-min increase in insulin concentrations, whereas a continuous abomasal infusion evoked no insulin response (Vicini et al., 1988).

Plasma urea concentration increased in response to both the ARG - and ARG + treatments with the response being greater for the ARG+ treatment. The increase in urea indicates that AA supplied in excess of that needed for the increased protein synthesis were being deaminated, thus supplying the ammonia for entry into the urea cycle. With the ARG+ treatment, it appears appreciable amounts of Arg were being absorbed from the intestine and that the excess was converted to urea. Vicini et al. (1988) also reported an increase in urea concentration with an abomasal infusion of Arg.

\section{CONCLUSIONS}

The response of milk, protein, and lactose yields to an EAA infusion was not impaired by deletion of Arg from the infusate, indicating that Arg was not limiting the milk response with the ARG - treatment, although mammary uptake of Arg decreased with deletion of Arg. To support the milk response to the EAA infusions, mammary uptake of the group 1 AA increased just enough to support the increased milk protein yield, but for group $2 \mathrm{AA}$, the increased uptake was in excess of the milk protein response. Although milk lactose yield increased with EAA supplementation, mammary uptake of glucose and other energetic precursors did not increase. Group 2 AA seemed to play a major role in the response of both milk protein and lactose yield induced by EAA infusion.

\section{ACKNOWLEDGMENTS}

The authors thank T. Whyte and A. Hayirli (University of Alberta, Edmonton, AB, Canada) for their help in planning and conducting the study, and the staff at the University of Alberta Dairy Research and Technology Centre for the care of the experimental animals. We also thank M. Léonard, J. Renaud (Dairy and Swine Research and Development Centre, Agriculture and Agri-Food Canada, Sherbrooke, QB, Canada), and J. Montgomery (University of Alberta) for the laboratory analysis of the milk, plasma, and feed samples. Finally, we acknowledge the Alberta Livestock Industry Development Fund and Alberta Milk for their financial support of this project.

\section{REFERENCES}

Alumot, E., I. Bruckental, A. Tadmor, C. Kennit, and P. Holstein. 1983. Effect of proline on arginine uptake and nitrogen metabolism of lactating goats. J. Dairy Sci. 66:1243-1247.

Basch, J. J., E. D. Wickham, and H. M. Farrell Jr.. 1997. Arginase in lactating bovine mammary glands: Implications in proline synthesis. J. Dairy Sci. 80:3241-3248.

Benson, J. A., C. K. Reynolds, P. C. Aikman, B. Lupoli, and B. E. Beever. 2002. Effects of abomasal long chain fatty acid infusion on splanchnic nutrient metabolism in lactating dairy cows. J. Dairy Sci. 85:1804-1814.

Bequette, B. J., F. R. C. Backwell, and L. A. Crompton. 1998. Current concepts of amino acid and protein metabolism in the mammary gland of the lactating ruminant. J. Dairy Sci. 81:2540-2559.

Berthiaume, R., M. C. Thivierge, R. A. Patton, P. Dubreuil, M. Stevenson, B. W. McBride, and H. Lapierre. 2006. Effect of ruminally protected methionine on splanchnic metabolism of amino acids in lactating dairy cows. J. Dairy Sci. 89:1621-1634.

Bertolo, R. F. P., J. A. Brunton, P. B. Pencharz, and R. O. Ball. 2003. Arginine, ornithine, and proline interconversion is dependent on small intestinal metabolism in neonatal pigs. Am. J. Physiol. Endocrinol. Metab. 284:E915-E922.

Bickerstaffe, R., E. F. Annison, and J. L. Linzell. 1974. The metabolism of glucose, acetate, lipids and amino acids in lactating dairy cows. J. Agric. Sci. (Camb.) 82:71-85.

Bruckental, I., I. Ascarelli, B. Yosif, and E. Alumot. 1991. Effect of duodenal proline infusion on milk production and composition of dairy cows. Anim. Prod. 53:299-303.

Calder, A. G., K. E. Garden, S. E. Anderson, and G. E. Lobley. 1999 Quantitation of blood and plasma amino acids using isotope dilution electron impact gas chromatography/mass spectrometry with U- ${ }^{13} \mathrm{C}$ amino acids as internal standards. Rapid Commun. Mass Spectrom. 13:2080-2083.

Canadian Council on Animal Care. 1993. Guide to the Care and Use of Experimental Animals. Vol. 1. 2nd ed. E. D. Olfert, B. M. Cross, and A. A. McWilliam, ed. CCAC, Ottawa, ON, Canada.

Cant, J. P., E. J. DePeters, and R. L. Baldwin. 1993. Mammary amino acid utilization in dairy cows fed fat and its relationship to milk protein depression. J. Dairy Sci. 76:762-774.

Chew, B. P., J. R. Eisenman, and T. S. Tanaka. 1984. Arginine infusion stimulates prolactin, growth hormone, insulin, and subsequent lactation in pregnant dairy cows. J. Dairy Sci. 67:2507-2518.

Clark, J. H. 1975. Lactational responses to postruminal administration of proteins and amino acids. J. Dairy Sci. 58:1178-1197. 
Clark, J. H., R. G. Derrig, C. L. Davis, and H. R. Spires. 1975. Metabolism of arginine and ornithine in the cow and rabbit mammary tissue. J. Dairy Sci. 58:1808-1813.

Doepel, L., and H. Lapierre. 2010. Changes in production and mammary metabolism of dairy cows in response to essential and nonessential amino acid infusions. J. Dairy Sci. 93:3264-3274.

Doepel, L., M. Lessard, N. Gagnon, G. E. Lobley, J. F. Bernier, P. Dubreuil, and H. Lapierre. 2006. Effect of glutamine supplementation on immune response and milk production in dairy cows. J. Dairy Sci. 89:3107-3121.

Doepel, L., G. E. Lobley, J. F. Bernier, P. Dubreuil, and H. Lapierre. 2007. Effect of glutamine supplementation on splanchnic metabolism in lactating dairy cows. J. Dairy Sci. 90:4325-4333.

Emery, R. S., L. D. Brown, and J. W. Bell. 1965. Correlation of milk fat with dietary and metabolic factors in cows fed restricted-roughage rations supplemented with magnesium oxide or sodium bicarbonate. J. Dairy Sci. 48:1647-1651.

Grimble, R. F., and R. G. Whitehead. 1970. Changes in the concentration of specific amino acids in the serum of experimentally malnourished pigs. Br. J. Nutr. 24:557-564.

Hanigan, M. D., J. P. Cant, D. C. Weakley, and J. L. Beckett. 1998. An evaluation of postabsorptive protein and amino acid metabolism in the lactating dairy cow. J. Dairy Sci. 81:3385-3401.

Huntington, G. B. 1984. Net absorption of glucose and nitrogenous compounds by lactating Holstein cows. J. Dairy Sci. 67:1919 1927.

Lapierre, H., L. Doepel, E. Milne, and G. E. Lobley. 2009. Responses in mammary and splanchnic metabolism to altered lysine supply in dairy cows. Animal 3:360-371.

Lemosquet, S., G. Raggio, P. Faverdin, J. Guinard-Flament, C. Hurtaud, J. Van Milgen, and H. Lapierre, 2010. How increasing protein supply or glucogenic nutrients modify mammary metabolism in lactating dairy cows. 3rd EAAP Intl. Symp. Energy and Protein Metabolism, Parma, Italy. EAAP, Rome, Italy.

Mepham, T. B. 1982. Amino acid utilization by lactating mammary gland. J. Dairy Sci. 65:287-298.

Metcalf, J. A., L. A. Crompton, D. Wray-Cahen, M. A. Lomax, J. D. Sutton, D. E. Beever, J. C. MacRrae, B. J. Bequette, F. R. C. Backwell, and G. E. Lobley. 1996. Responses in milk constituents to intravascular administration of two mixtures of amino acids to dairy cows. J. Dairy Sci. 79:1425-1429.
National Research Council. 2001. Nutrient Requirements of Dairy Cattle. 7th rev. ed. Natl. Acad. Sci., Washington, DC

Novak, S., B. K. Treacy, F. R. C. L. Almeida, J. Mao, W. C. Buhi, W. T. Dixon, and G. R. Foxcroft. 2002. Regulation of IGF-I and porcine oviductal secretory protein (pOSP) secretion into the pig oviduct in the peri-ovulatory period, and effects of previous nutrition. Reprod. Nutr. Dev. 42:355-372.

Raabo, E., and T. C. Terkildsen. 1960. On the enzymatic determination of blood glucose. Scand. J. Clin. Lab. Invest. 12:402-407.

Raggio, G. 2006. Effets des apports protéiques et énergétiques sur le métabolisme protéique chez la vache laitière. $\mathrm{PhD}$ Thesis. Université Laval, Québec, Canada, and ENSA, Rennes, France.

Raggio, G., S. Lemosquet, G. E. Lobley, H. Rulquin, and H. Lapierre. 2006. Effect of casein and propionate supply on mammary protein metabolism in lactating dairy cows. J. Dairy Sci. 89:4340-4351.

Roets, E., R. Verbeke, G. Peeters, H. Axmann, and G. Proksch. 1979 Metabolism of ornithine in perfused goat udder. J. Dairy Sci. 62:259-269.

Rulquin, H., G. Raggio, H. Lapierre, and S. Lemosquet. 2007. Relationship between intestinal supply of essential amino acids and their mammary metabolism in the lactating dairy cows. Pages 587-588 in Energy and Protein Metabolism and Nutrition. I. Ortigues-Marty, ed. EAAP Publication No. 124, Rome, Italy.

SAS Institute. 1999. SAS System for Mixed Models. SAS Inst. Inc., Cary, NC

Swaisgood, H. E. 1995. Protein and amino acid composition of bovine milk. Pages 464-468 in Handbook of Milk Composition. R. G. Jensen., ed. Academic Press, Toronto, ON, Canada.

Van Soest, P. J., J. B. Robertson, and B. A. Lewis. 1991. Methods for dietary fiber, neutral detergent fiber and non-starch polysaccharide in relation to animal nutrition. J. Dairy Sci. 74:3583-3597.

Vicini, J. L., J. H. Clark, W. L. Hurley, and J. M. Bahr. 1988. Effects of abomasal or intravenous administration of arginine on milk production, milk composition and concentrations of somatotropin and insulin in plasma of dairy cows. J. Dairy Sci. 71:658-665.

Weekes, T. L., P. H. Luimes, and J. P. Cant. 2006. Responses to amino acid imbalances and deficiencies in lactating dairy cows. J. Dairy Sci. 89:2177-2187.

Williamson, D. H., and J. Mellanby. 1974. D-(-)-3-Hydroxybutyrate. Page 1836 in Methods of Enzymatic Analysis. Vol. IV. H. U. Bermeyer, ed. Academic Press, New York, NY. 